the one described above. Through the good offices of Dr. J. A. Boycott, serum specimens collected from the patient on 23 September and 12 October were sent to the other of us (H. S.) for examination for cytomegalovirus antibodies. The complement-fixing antibody titres were found to be 8 and 512 respectively. A further serum taken on 1 February 1966 had a titre of 256 ; urine specimens collected at this time were examined for virus excretion but without success.

The clinical course and laboratory findings of our patient closely followed the pattern described by the Finnish workers, and we would agree with their conclusion that cytomegalovirus infection must be considered as a possible cause of atypical, Paul-Bunnellnegative, infectious mononucleosis.-We are, retc.,

Chest and Isolation Hospital
Taunton, Somerset.

\section{J. P. ANderson.}

HAROLD STERN.

Department of Virology,

St. George's Hospital Medical School, London S.W.1.

\section{Trusses for Femoral Hernia}

SIR,-While agreeing with Mr. F. Welsh (26 February, p. 545) in the condemnation of femoral trusses in general, there is a small group of patients in whom they are safe and efficient-that is, those with an ankylosed hip-joint.

When this joint is fixed there are no movements to displace the pad, and provided that the hernia is reducible it can be controlled by a properly fitted truss.

I have had under my care two elderly females each with a femoral hernia and an ankylosed hip, one due to tuberculosis in childhood and the other following surgical intervention for osteoarthritis. They were each fitted with a truss, and, as far as the hernia was concerned, both lived for several years in comfort and safety.-I am, etc.,

$$
\text { London W.1. } \quad \text { R. J. MCNeILL Love. }
$$

\section{Diagnosis and Management of Pneumonia in the Aged}

SIR,-Dr. E. Woodford-Williams's article in "Current Practice" (19 February, p. 467), while providing a much needed and thorough review of the subject, makes a few statements which I feel require further consideration.

First, is penicillin the drug of choice in these patients? Dr. Williams states that lobar pneumonia caused by a specific organism is not as frequently seen in these patients as is aspiration pneumonia. Her first choice of antibiotic in this condition is penicillin G. Surely this is an incongruity, for the prevalent organism in this condition is undoubtedly Haemophilus influenzae, a stubborn adversary which has little fear of penicillin G. Secondly, is it wise to await the bacteriological or therapeutic test before giving a broad-spectrum antibiotic, parenterally if necessary? Penicillin $G$ at this stage would appear to be a gamble. If it fails the two or three days of extra toxicity may well be lethal. Surely it is more logical to initiate treatment with a broad-spectrum drug and revert to penicillin later if the bacteriological findings suggest this. In the same paragraph it is recommended that, "Additionally, in severe cases, streptomycin, $0.5 \mathrm{~g}$. intramuscularly b.d., should be given for four or five days-in this dosage damage to the eighth nerve is rare." One is tempted here to ask how rare is "rare." Basing my views on a considerable experience of the treatment of tuberculosis I would venture the dictum that no patient over 60 years should ever receive such doses even for four days. Streptomycin blood-levels escalate steeply where kidney function is faulty, and the impending or actual renal failure, often induced by dehydration, anoxia, or cardiac failure, and so rightly emphasized by Dr. Williams, is surely an added reason for a total ban on this drug in geriatric practice. There is a further good reason for this ban. An initial course of streptomycin such as Dr. Williams advises is quite likely to result in a negative sputum smear for tubercle bacilli, and so a diagnosis of what has now become a relatively common geriatric condition may be missed.
With regard to anoxia the writer feels that Dr. Williams's references are inadequate and that the emphasis on "severe cyanosis" as a pointer in diagnosis is dangerously complacent. The statement that adverse reaction to oxygen therapy is not very common but is important is surely wrong. One thing is certain-if oxygen is frequently given in a haphazard fashion in respiratory disease then adverse reactions to oxygen therapy will, far from being " not very common," become extremely common. Dr. Williams has surely sinned by omission in not mentioning the importance of early $\mathrm{PCO}_{2}$ estimations in the management of these patients. Such estimations, taking up no more than five minutes' time, can of course be carried out if necessary by the general practitioner in the patient's home by the rebreathing technique. -I am, etc.,

$$
\begin{aligned}
& \text { St. Kevin's Hospital, JohN J. Fl.ANAGAN. } \\
& \text { Dublin. }
\end{aligned}
$$

\title{
Seasonal Distribution of Deaths from Cancer
}

SIR,-In 1927 Pirquet $^{1}$ noted that in England and Wales in 1912-20, excluding 1918-19, deaths from cancer were anomalous in being least frequent in the second quarter of the year and most frequent in the fourth quarter. In 1933 Geréb $^{2}$ confirmed this observation, using German data of 1926-31;

TABLE I.-Quarterly Incidence of Cancer and Non-cancer Deaths in England and Wales, 1956-63

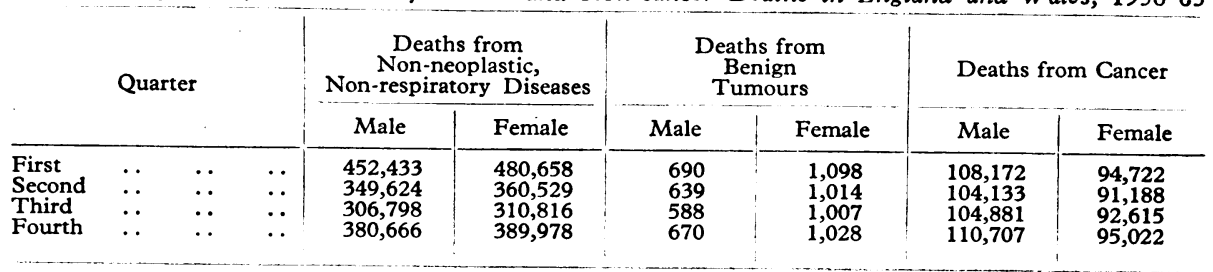

\begin{tabular}{|c|c|c|c|c|c|c|c|c|c|}
\hline \multicolumn{4}{|c|}{ Season of Deaths } & \multicolumn{2}{|c|}{$\begin{array}{c}\text { Deaths from } \\
\text { Non-neoplastic, } \\
\text { Non-respiratory Diseases }\end{array}$} & \multicolumn{2}{|c|}{$\begin{array}{c}\text { Deaths from } \\
\text { Benign } \\
\text { Tumours }\end{array}$} & \multicolumn{2}{|c|}{ Deaths from Cancer } \\
\hline & & & & Male & Female & Male & Female & Male & Female \\
\hline $\begin{array}{l}\text { Winter } \\
\text { Spring } \\
\text { Summer } \\
\text { Autumn } \\
\end{array}$ & $\begin{array}{l}. \\
\cdots \\
\cdots \\
\end{array}$ & $\begin{array}{l}\cdots \\
\cdots \\
\cdots \\
\end{array}$ & $\begin{array}{l}\cdots \\
\cdots \\
\cdots \\
\end{array}$ & $\begin{array}{l}455,201 \\
382,798 \\
311,561 \\
339,961 \\
\end{array}$ & $\begin{array}{l}478,444 \\
401,194 \\
316,314 \\
346.029 \\
\end{array}$ & $\begin{array}{l}704 \\
654 \\
617 \\
612 \\
\end{array}$ & $\begin{array}{r}1,127 \\
988 \\
1,019 \\
1,013 \\
\end{array}$ & $\begin{array}{l}110,042 \\
104,850 \\
104,193 \\
108,808 \\
\end{array}$ & $\begin{array}{l}95,267 \\
91,940 \\
91,817 \\
94.523 \\
\end{array}$ \\
\hline $\begin{array}{l}\text { Spring } \\
\text { Autumn }\end{array}$ & $\begin{array}{l}. \\
.\end{array}$ & 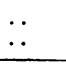 & $\cdots$ & $\begin{array}{l}382,798 \\
339,961\end{array}$ & $\begin{array}{l}401,194 \\
346,029\end{array}$ & $\begin{array}{l}654 \\
612 \\
\end{array}$ & $\begin{array}{r}988 \\
1,013 \\
\end{array}$ & $\begin{array}{l}104,850 \\
108,808\end{array}$ & $\begin{array}{l}91,940 \\
94,523 \\
\end{array}$ \\
\hline $\begin{array}{l}\text { Spring } \\
\text { Autumn } \\
\end{array}$ & $\because$ & $\because$ & $\cdots$ & \multicolumn{2}{|c|}{$\begin{array}{l}783.992 \\
685,990 \\
\end{array}$} & \multicolumn{2}{|c|}{$\begin{array}{l}1,642 \\
1,625 \\
\end{array}$} & \multicolumn{2}{|c|}{$\begin{array}{l}196,790 \\
203,331\end{array}$} \\
\hline S./A. & $\cdots$ & $\cdots$ & . & \multicolumn{2}{|c|}{$1 \cdot 14$} & 1.07 & 0.98 & \multicolumn{2}{|c|}{0.97} \\
\hline
\end{tabular}

TABLE II.-Seasonal Incidence of Cancer and Non-cancer Deaths in England and Wales, 1956-63

TABLE III.-Spring and Autumn Deaths from Cancer in England and Wales, 1956-63

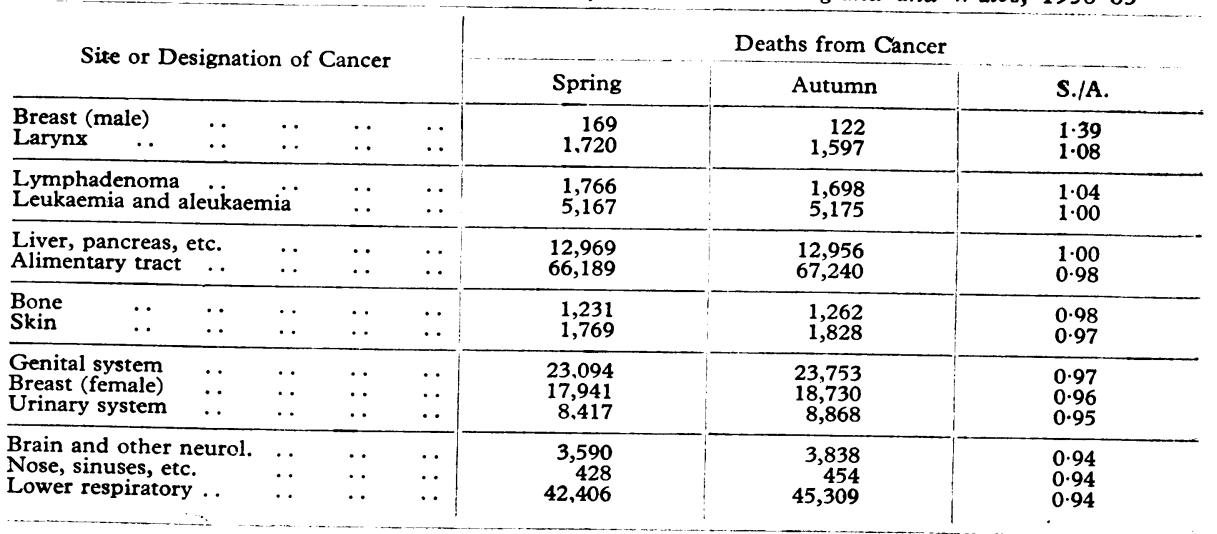
1956-63 $3^{3}$ In for England and Wales in the numbers have been adjusted on the basis of a 31-day month.

Table II shows, further, that in England and Wales in $1956-63^{3}$ deaths from cancer nd Table I confirms it further by means 
(and also female deaths from benign tumours) were anomalous in being considerably less frequent in spring (March-April-May) than in autumn (September-October-November). And Table III shows that this anomaly was characteristic, though unequally so, of most of the individual cancer sites.

Of the very few non-neoplastic diseases which were similarly anomalous in England and Wales in 1956-633 the two with the lowest ratio of spring to autumn deaths were simple goitre, namely 0.72 (33:46), and avitaminoses (in females), namely 0.76 $(121: 160)$. In contrast, the corresponding ratio at the other extreme for thyrotoxicosis, namely 1.35 (750:554), and for non-toxic nodular goitre, namely $1.41(55: 39)$. This last was next highest to the ratio for respiratory diseases, namely $1.43(140,512: 97,999)$.

Geréb ${ }^{2}$ found that cancer deaths were least frequent in March and April, and as a possible explanation of this he suggested vitamin lack, citing experimental evidence of the inhibiting effect of vitamin lack on tumour growth, and also evidence, consistent with this, of seasonal variation in tumour growth. Speculation as to causes, however, is likely to be unfruitful until at the least a much more extensive and sophisticated analysis has been made, not only of British and German data but also of corresponding data from other latitudes and longitudes.-I am, etc.,.

$$
\begin{gathered}
\text { Royal Infirmary, } \\
\text { Aberdeen. }
\end{gathered} \quad \text { T. M. Allan. }
$$

\section{REFERENCES}

' Pirquet, C., Z. Kinderheilk., 1927, 44, 413.

, Geréb, P., Z. Krebstorsch., 1933, 39, 104. Tables, Medical, 1956-63. H.M.S.O., London.

\section{Case of Traumatic Subcutaneous Rupture of the Abdominal Wall}

SIR,-Injuries to the abdominal contents are common and well documented both in textbooks and journals. Injuries to the abdominal wall other than incised wounds are uncommon, however, and the following case report may be of interest.

A 4-year-old boy was sent in to hospital by his general practitioner following a fall off a wall. There was no adult witness of the accident, but it is probable that he had fallen from a height of about six feet on to a pile of corrugated iron sheets. On examination on admission he was fully conscious and no shocked. He had lacerations of the right side of his neck and left arm and a tender, swollen, bruised area measuring about $7 \mathrm{~cm}$. by $3 \mathrm{~cm}$. below and parallel to his right rib margin in the loin. On one occasion when this swelling was palpated it gurgled. There was tenderness and some guarding in his right upper abdomen and loin. $X$-rays of his chest and abdomen were normal except that the swelling was visible as a bulge which contained gas. The gas was enclosed in what looked like colon, but there was no clear communication between it and the normal colonic shadow.

Under a general anaesthetic his neck and arm lacerations were explored and sutured and his abdomen was opened through a small incision below the right costal margin medial to the swelling in the loin. Through this incision it was ascertained that there was no intraperitoneal damage in the right side of the abdomen except a little bruising of the mesentery of the hepatic flexure of the colon. At the site of the swelling, however, the peritoneum and the full thickness of the muscle wall (comprising at this point transversus abdominis, internal oblique, and external oblique) had béen torn across in a line parallel to the rib margin. The colon had obviously entered the hernia and been in contact with the under surface of the skin. This skin over the hernia was incised and both the traumatic and operative wounds repaired in layers. The boy's recovery was straightforward and all his wounds were soundly healed when he was seen six weeks after discharge.

The points of interest in this case are (a) the rarity of the condition, and (b) the mechanism of injury.

We don't know how this boy injured himself, but Jamieson,' describing a similar hernia in an adult, postulates that the abdominal wall is forced against a small immovable object while the muscles are tightly contracted and therefore rigid. The overlying skin and underlying viscera escape injury because of their elasticity. In the only other case report which I have been able to find $^{2}$ a 9 -year-old boy fell off his bicycle and struck his abdomen against one of the handlebars. In this case the peritoneum was not damaged and formed a hernial sac.

I am grateful to Mr. I. S. Kirkland for permission to publish this case.

$$
\text { -I am, etc., }
$$

Edinburgh 3.

\section{A. J. Dougall.}

\section{REFERENCES}

Jamieson, R. A., Brit. 7. Surg., 1949, 36, 434.
Roberts, G. R., Ibid., 1964, 51, 153.

\section{Fortuitous Therapy for Psoriasis}

SIR,-After having read your correspondence regarding fortuitous therapy for psoriasis (26 February, p. 544) I would like to bring the following interesting case to your notice.

The patient was a young married woman 35 years old. She had had chronic psoriasis for a number of years. The psoriasis had been treated in hospital with steroid applications and occlusions without much improvement.

Quite suddenly for no apparent reason her psoriasis cleared completely. Two days later she had a myocardial infarct for which she was admitted to hospital.

She improved and her psoriasis returned, but was not so severe as before. Unfortunately seven weeks after her first infarct she had a second one and died.-I am, etc.,

$$
\begin{aligned}
& \text { Sutton in Ashfield, } \\
& \text { Notts. }
\end{aligned}
$$

\section{Contact Dermatitis from Spandex Yarn}

SiR,-We wish to draw attention to a number of cases of contact dermatitis following the wearing of a particular type of brassière. The dermatitis occurs under the elastic panels of the garment, which is made of a synthetic yarn known as Spandex. Sensitization appears to be due to the presence of an anti-oxidant, mercaptobenzthiazole, which is used in the manufacture of Spandex.

Dermatitis from clothing occurs not uncommonly. ${ }^{1}$ Wilson ${ }^{1}$ reported eight cases of dermatitis under brassières or corsets associated with sensitivity to rubber, and also with sensitivity to rubber gloves. Some of these cases were sensitive to mercaptobenzthiazole. Formalin dermatitis from urea formaldehyde and melamine formaldehyde in drip-dry clothing has been described, ${ }^{2}$ as has dermatitis from $\mathrm{khaki}^{3}$ and nylon-stocking. dermatitis. The patterns of clothing dermatitis have been described by Wilkinson. ${ }^{5}$

Dermatitis from Spandex yarn is localized in the first instance to areas of skin which are in contact with panels of the brassière made of this fabric, and presents a characteristic picture. It affects skin in contact with all areas of the brassière apart from the cupsthat is, at the back-ceasing two inches ( 5 $\mathrm{cm}$.) from the mid-line, and on the front of the chest appearing in a narrow $\mathrm{V}$ above the breasts, where strips of the same material are used. Usually the dermatitis appears initially as an acute erythema, followed by scaling and sometimes by pigmentation. The dermatitis may become more widespread, for once established there may be cross-sensitivity with rubber in other elastic threads, as the antioxidant mercaptobenzthiazole is also present in most rubber garments.

Spandex thread is a manufactured fibre consisting of a long-chain synthetic polymer, of which at least $85 \%$ is a segmented polyurethane.

In the past four months we have investigated 11 patients suffering from this type of dermatitis. They had all been wearing brassières of one make, and the dermatitis had occurred after the garments had been worn for a period varying from one to three months. In all patients positive patch tests were found to parts of the brassiere made of Spandex antd to mercaptobenzthiazole $1 \%$ in soft yellow paraffin. Other pieces of the brassière, formalin, azo dyes, and Lycra yarn, an expanded polyurethane (whicb does not contain mercaptobenzthiazole), were all negative. Two patients were positive to rubber and one to tetramethyl thiuram monosulphide $1 \%$ in soft yellow paraffin.

As this is a widely advertised brassière, of which a large number are sold, contact dermatitis from this garment is not very common, but as cases have occurred in other parts of the country ${ }^{6-9}$ we feel our cases should be recorded.

We would like to thank Dr. H. T. Calvert, Dr. M. Feiwel, Dr. R. Vickers, and Dr. D. S. Wilkinson for asking us to investigate their patients, and Mr. W. R. Shaw for supplies of various materials.

-We are, etc.,

C. F. Allenby.

K. D. Crow

V. KIRTON.

D. Munro-Ashman.

Royal Berkshire Hospital, Reading.

REPERENCES

1 Wilson, H. T. H., Brit. med. F., 1960, 2, 21 2 Cronin, E., Brit. ' Y. Derm., 1963, 75, 267 . Hodgson, G. A.. and $1946,87,110$

Calnan. C. D., and Wilson, H. T. H., Brit. med F, 1956, 1, 147.

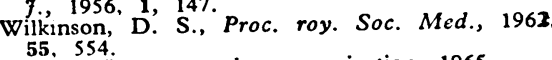

- Forman, L., personal communication, 1965

'Hall-Smith, personal communication, 1965.

Morgan, J. K., personal communication, 1965.

\section{Aspergillosis Tests}

SIR,-Pepys and his colleague ${ }^{1}$ have conclusively demonstrated the value of demonstrating precipitating antibodies in the diagnosis of infections by species of Aspergillus. It has come to my notice that in order to free their research facilities for other 